\title{
Mature B-Cell Non-Hodgkin Lymphoma
}

National Cancer Institute

\section{Source}

National Cancer Institute. Mature B-Cell Non-Hodgkin Lymphoma. NCI Thesaurus. Code C7056.

A non-Hodgkin lymphoma that originates from mature B lymphocytes. Representative examples include diffuse large B-cell lymphoma, follicular lymphoma, marginal zone lymphoma, mantle cell lymphoma, and small lymphocytic lymphoma. 